\title{
Green Space Conceptual Design for the Neighbourhood of Settlements along Martapura River in Banjarmasin
}

\author{
Hanny Maria Caesarina* \\ Urban and Regional Planning Department, Faculty of Engineering, University of Muhammadiyah Banjarmasin, Jl. Gubernur \\ Syarkawi, Barito Kuala
}

\begin{abstract}
Banjarmasin still struggles to improve the environment quality of the settlements in some riparian area that built directly above Martapura river. The settlements are densely populated with limited pathways without any open space. The local government implemented waterfront development to improve the environmental quality, such as green village concept by installing some greeneries along the settlements to create a greener neighbourhood. The main problem was there were no available land for greenspace. The aim of this research was to design a conceptual design for green space along the river based on the evaluation of the existing condition after green village concept already implemented. Series of field observation, interviews and literature review were done to get actual condition of the study area. The data analysed with descriptive-qualitative approach and resulted that the quality of the green space in the neighbourhood can be improved with a special green space design for the limited space. We produce a conceptual design that fulfil the criteria of green space for settlements along the Martapura river which are vertical garden, floating communal space and floating garden These concepts may suitable for green space in limited space and connected with the river as blue space.
\end{abstract}

Keyword: concept; design; green space; neighbourhood; river

\section{Introduction}

The design of green and sustainable neighbourhood derives from sustainable development which obliges a balance between environmental improvement, economic growth and social expansion. As been stated in Brundtland Report-1987, sustainable development also means how to meet the needs and aspirations of the present without compromising the ability of the future generation (Riddell, 2004). This thought has been initiated as the concern of natural systems problems that should be tied together with the social and economic challenges. Indonesia firstly incorporated the sustainable development concept to the development plan in1989 in forms of Indonesia's Five-Year Development Plan. This small step of sustainable concept still continues until nowadays, even though more concerns are mostly in the environmental problems.

Nevertheless, sustainable neighborhood as part of sustainable development is still considered to be a new concept in Banjarmasin. Before this concept were introduced, Banjarmasin was more familiar with green city concept which has 8 (eight) main elements, which are: green planning and design; green water; green open space ; green waste; green transportation, green energy; green community; and green building (Pekerjaan Umum dan Perumahan Rakyat, Jenderal Cipta Karya, \& Bina Penataan Bangunan, 2017). The focus of green city mostly on how to manage land, water and air in an effective way. The three Es (Environment, Economy and Equity) of sustainable concept which are the basic foundation of sustainable urban planning and design (Cities, 2010; Riddell, 2004) also been called as "GrEEEn" framework (Goell, Nisreen, Hussen, El-Khishin, \& Soliman, 2009; Sandhu \& Singru, 2014) that aims to achieve and improvement in environmental quality.

\footnotetext{
* Corresponding author : Hanny Maria Caesarina

E-mail address: hanny.planarch@gmail.com
} 
Green space is one element of sustainable neighborhood (Johar \& Razak, 2015) and holds an important role in "greening" the neighborhood. Green space holds a vital role in every city in the world. Many cities form their green space in order to overcome the degradation of environmental quality. Air pollution, flood, and the lack of social spaces makes green space to be a perfect solution of those problems. Most studies shows that urban green space provides ecosystem services through ecological system as well as promoting so many social and physical activity which benefits the city in many ways(Bank, 2012; Darieva, 2015; Dwiyanto, 2009; El Ghorab \& Shalaby, 2016; Hartig, Mitchell, de Vries, \& Frumkin, 2014; Johar \& Razak, 2015; Tzoulas et al., 2007).

Green space is not always distributed equitably within cities due to so many factors such as history of land development, philosophy of urban landscape design, etc. This issue creates uneven green quality of a city. Sometimes one neighborhood considered to be greener than the other. However, this condition might occur differently according to the typology of the neighborhood itself. The neighborhood that forms from settlements along the river can easily be found in Banjarmasin, the thousand river city.

Many of the previous researches in Banjarmasin discuss about the typology and land use of the settlements along the river. Most of the settlements were built above the River which often called as settlement along the River (Goenmiandari, 2010; Nurisyah, 2011). However, there are still very little researches already done regarding the issue of green space along the settlements in Martapura River. The settlements only provides very limited space for green space in form of greeneries (Caesarina \& Aina, 2018), while many of the citizens express their need for an actual green space (Caesarina, Humaida, Amali, \& Wahyudi, 2019). Parks, green roofs, streams, community garden, sport fields, nature conservation areas and green streams area are some of urban green spaces that helps improve environmental quality of a neighbourhood with limited land(Sandhu \& Singru, 2014). Green space supports to minimize pollution, produces clean air, cooling down temperature, creating sun shading and these positive impacts also helps improving public health (Wolch, Byrne, \& Newell, 2014).

\section{Methodology}

This research was conducted in two study area of settlements along Martapura River of Banjarmasin. The first one is Seberang Mesjid district and the second one is Sungai Bilu districts. These two areas were picked based on their location which are in the heart of the city and each of them located almost next to each other; the neighborhoods each have strong connection to Martapura River; each of the neighborhood has been developed based on waterfront development plan from the Municipality of Banjarmasin. These two neighborhoods well known of their settlement along Martapura River but slightly have different typology.

This paper identify the character of green space in settlement along Martapura River which also known as riverbank settlement (Goenmiandari, 2010), river settlement(Lin, Shaad, \& Girot, 2016), waterfront residential (Hagerman, 2007; Yassin, Eves, \& Mcdonagh, 2010) and stream corridor settlement (Caesarina \& Aina, 2018). Even though many other researches have used many other phrase to picture the settlements that built above the river, we chose settlement along Martapura River as the phrase used in this research based on the geographical location of the area for about $1,7 \mathrm{Km}$ length along Martapura River.

The main goal of this research is to design a conceptual design based on the existing condition of the green space in settlements along Martapura river. Field observation and indepth interview with local residents were done to get clear picture regarding the availability of green space due to the waterfront development since November 2016-May 2018. Interviews and questionnaires were done with 100 local residents (indigenous people) regarding the impact of the pilot project to their neighbourhood environmental quality, safety and social activities. This research defined the condition of the neighbourhood before and after the waterfront development and how the local people react to the condition. The researcher also did some literature review regarding government regulation for urban green space in Indonesia, and some best practice for green space that has almost similar characteristic to the study area, which are located at the edge of riparian area. The data then analyzed using triangulation approach to 
define the qualification for green space for settlements along Martapura river, in order to find a suitable conceptual design for the study area.

\section{Results and Discussions}

\subsection{Green Space Regulation and Banjarmasin's Policy}

Indonesia has a specific regulation regarding green space, which is Peraturan Menteri Pekerjaan Umum Nomor 01/PRT/M/2008 (Indonesia Public Service Ministry Regulation) about the guidelines of urban green space in Indonesia (Direktorat Jendral Penataan Ruang. Department Pekerjaan Umum, 2008). This regulation specifically states that every city and urban area need to provide public green space (20\% from total area) and private green space (10\% from total area). This regulation also mentions about blue space, where the river, ponds and lake should be taken into consideration in every urban area. Nevertheless, this section about blue space is not specifically detailed. The whole regulation only provides guidelines for green space in urban area where land are still available, focus more about providing space for water infiltration, with no attention for blue space. It mentions that urban area that only has very limited space can provide several potted plants, vertical plants or even roof garden.

In this research, the study areas happens to be a settlement's neighbourhood along Martapura river which were built above the river. The areas have a large blue space and located at the edge of riparian area. Banjarmasin even has specific policy regarding the settlement along the river. Most of the city in Indonesia need to obey the Public Law regarding riparian area along the river (Garis Sempadan Sungai-GSS) for minimum 15 metres long, while Banjarmasin still allows some of the cultural heritage settlements that already built above the river. These areas are considered to be the local identity of the city, and the Municipality always try to integrate river into the city's planning and design. A good blue-green space design can also contribute to minimize the flood risk of a city (Wright, Thorne, \& Lawson, 2014). As for the guidelines for urban green space, Banjarmasin still hold on to the regulation mention above.

\subsection{Green Space in Settlements along Martapura River}

Stream corridor and river has been part of Banjarmasin's local resident since many years ago. Even during the Dutch colonization era, river has been developed as an integral part of Banjarmasin. Promenade and green belt can be found along Martapura River. The geographical condition of wetland in Banjarmasin has made the river to be the center of the city's development. River has been part of Banjarmasin's resident for many years and the traditional culture and indigenous people mostly settled along one of the main rivers in Banjarmasin, namely Martapura River. Settlements along Martapura River are considered to be part of Banjarmasin heritage. The settlements are specifically built along the river in Banjarmasin and form a unique character of socio cultural activities (Goenmiandari, 2010; Nurisyah, 2011). However, the rapid urban development in the city have affected those settlements. Environmental degradation as the effect of urban development can be seen through water and air pollution.

The study area in this research are: Seberang Mesjid district and Sungai Bilu District. These areas are located in the centre of Banjarmasin and designed as strategic area of the city, according to Banjarmasin Spatial Plan. The Municipality already freed several areas along the stream corridors from settlements, only those considered have high value for culture and local tradition that still remain preserved above the river. Seberang Mesjid and Sungai Bilu are considered as cultural heritage area, because there areas still has houses that oriented to the river. Therefore these areas (around $2 \mathrm{kms}$ ) are still allowed to have settlements along Martapura river. The waterfront development that already implemented in these areas were done in 2017, where the Municipality tried to improve the environmental quality of the neighbourhood by installing some waste facilities and encourage the local people to have more plantation and vegetation in their neighbourhood. Sungai Bilu even namely as "Kampung Hijau" or translated as Green Village.

Based on field research and observation, both Seberang Mesjid and Sungai Bilu are having very limited land for green space. During daytime, there are no activities outside the 
settlements because there are no sun shading or big trees. These has lead the Municipality to initiatively install some potted plants as greeneries to make the area "greener". The settlements virtually built above the river with wooden pathways that has around 1 metre wide in front of each houses. Each settlements were built from wood, with around $80 \mathrm{~cm}$ terraces wide. Based on the Government regulation, each neighbourhood need to provide a park as public green space, as well as garden in each private urban area. However, the green space in the settlements along Martapura river are quite different.

There is only one big tree found in the area, which is Rambai tree, a local plant of South Borneo. No bushes were found in the area. Potted plants and hanging potted plants are available in the neighborhood which refers to private green space and can be categorized as un-natural green space. Each house received 5 to 6 potted plants from the Municipality and mostly are decorative plants (see figure 1) that has no function for sun shading. The local people initiatively added some local vegetable plants. These plants are: pohon limau kuit (lime tree which fruits are small, taste tangy and sweet), Lombok tiung (small chillies which are very hot), and seledri (celery). These plants are the ingredients for famous local soup called "Soto Banjar", and can be easily found in almost every terraces of the house. The locals also used ilung (local water hyacinth) as the media and fertilizer for their plants.
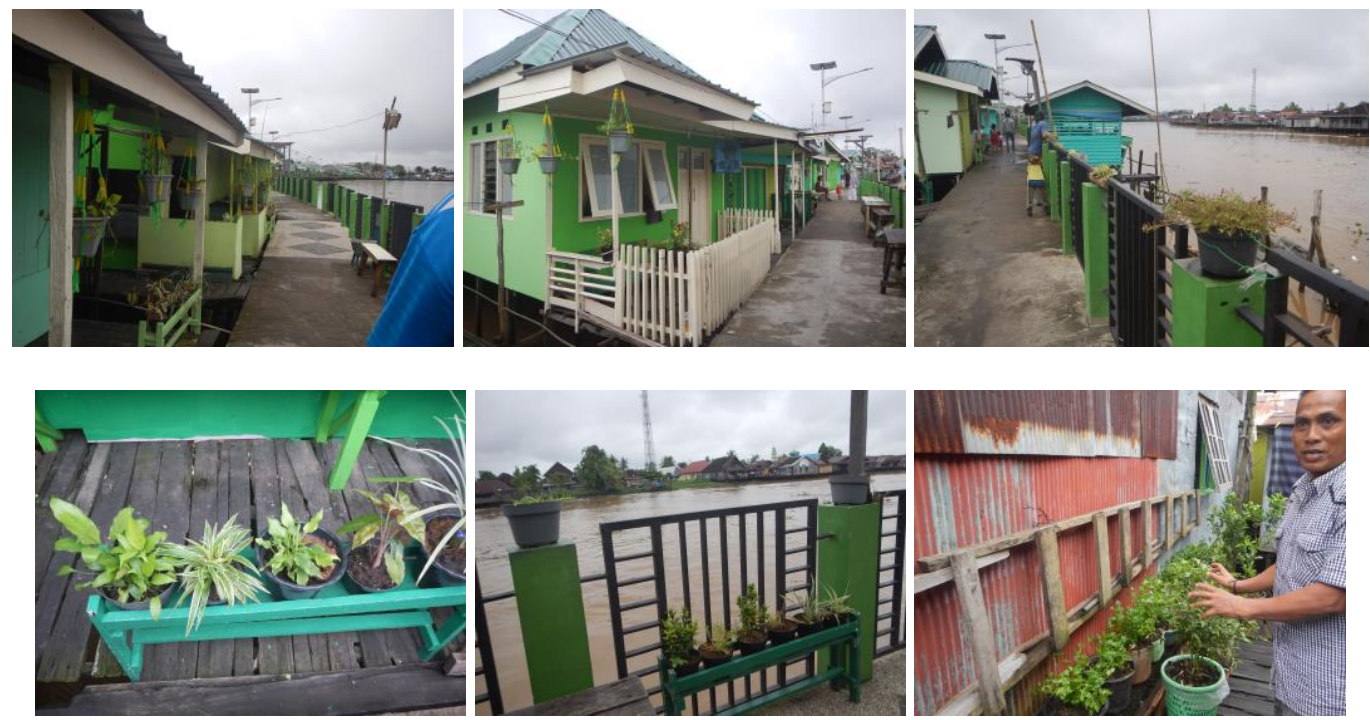

Figure 1. Distribution of Private Green Space (in each house) as Greeneries in the study area (Field Observation, 2018)

As can be seen from Table 1, the settlements in Seberang Mesjid and Sungai Bilu both still lack in quantity of green space. The existing green space only around 185-247 m2 which is only about $0,1 \%$ of the total standard needed. Overall, both of the neighbourhood already has public green space more than the private area of green space. However, these public green space are located in the riparian area and quite far from the settlements. Each of the neighborhood still needs a lot of improvement to achieve the standard quantity of green spaces and this actually give a huge opportunity to design green space along the settlements in many creative ways.

Table 1. Green Space in Seberang Mesjid and Sungai Bilu Settlement along Martapura River

\begin{tabular}{|c|c|c|c|c|}
\hline $\begin{array}{l}\text { Location of } \\
\text { Existing } \\
\text { Green Spaces }\end{array}$ & $\begin{array}{l}\text { Typology of Green } \\
\text { Space }\end{array}$ & $\begin{array}{l}\text { Existing } \\
\text { Green } \\
\text { Space } \\
(\mathrm{m} 2)\end{array}$ & $\begin{array}{l}\text { Green Space needed in every } \\
\text { local neighborhood according } \\
\text { to Standard }(\mathrm{m} 2) \text { (Direktorat } \\
\text { Jendral Penataan Ruang. } \\
\text { Department Pekerjaan Umum, } \\
2008)\end{array}$ & $\begin{array}{l}\text { Green Space } \\
\text { needed to } \\
\text { achieve the } \\
\text { Standard } \\
\text { (m2) }\end{array}$ \\
\hline $\begin{array}{l}\text { Seberang } \\
\text { Mesjid } \\
\text { Settlement }\end{array}$ & $\begin{array}{l}\text { Private Green Space } \\
\text { (Un-Natural Green } \\
\text { Space: aesthetic) }\end{array}$ & 41,92 & 666,67 & 624,75 \\
\hline
\end{tabular}




\begin{tabular}{|c|c|c|c|c|}
\hline \multirow{2}{*}{$\begin{array}{l}\text { along } \\
\text { Martapura } \\
\text { River }\end{array}$} & & & & \multirow[b]{2}{*}{1.191} \\
\hline & $\begin{array}{l}\text { Public (Natural) } \\
\text { Green Space }\end{array}$ & 142,823 & 1.333 & \\
\hline & TOTAL & 184,743 & 2.000 & $1.815,75$ \\
\hline \multirow{3}{*}{$\begin{array}{l}\text { Sungai Bilu } \\
\text { Settlement } \\
\text { along } \\
\text { Martapura } \\
\text { River }\end{array}$} & $\begin{array}{l}\text { Private Green Space } \\
\text { (Un-Natural Green } \\
\text { Space: aesthetic) }\end{array}$ & 23,68 & 666,67 & 643,99 \\
\hline & $\begin{array}{ll}\text { Public Green } & \text { Space } \\
\text { (Natural } & \text { Green } \\
\text { Space: } & \text { urban } \\
\text { ecology) } & \\
\end{array}$ & 246,870 & 1.333 & $1.086,13$ \\
\hline & TOTAL & 247,870 & 2.000 & 1.753 \\
\hline
\end{tabular}

\subsection{Local People's Opinion on Green Space Design after Waterfront Development}

Based on the interviewed with the local people, around $57 \%$ of them think that the waterfront development already gives some positive impacts and improvement to their area, while $43 \%$ of the local people still think that there is no improvement. We breakdown these opinions and came up with some conclusion that the local people feel that the Government only focus on the physical development without any further consideration to involve community in the project. As can be seen from Figure 2, the local people consider the improvement of cleanliness, good air quality, tourism and safety are the positive impacts from the waterfront development project (green tones in the diagram). On the other hand, there are $43 \%$ of local people who thinks the disadvantages after waterfront development which are: lack of support from local people and because the local people thinks their neighbourhood are still narrow for social activities (red tones). They said that there is still no space for social activities and the project itself never involve the local people. This result also almost similar with previous research which stated that the average index of green space value in settlements along Martapura river is around 13,75-20,82\% (Caesarina \& Aina, 2018) based on green space index from WHO (World Health Organization, 2017).

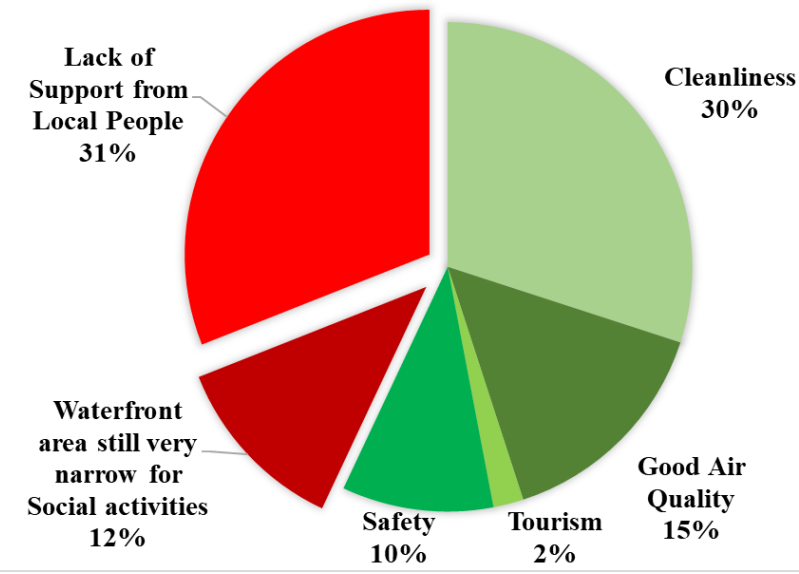

Figure 2. Distribution of Private Green Space (in each house) as Greeneries in the study area (Field Observation, 2018)

The waterfront development focused more on replacing the old pathway material from wood to concrete, and building fences to keep the local people stay away from the river, for safety reason. Interestingly, the local people think that the fences that built along the pathways are not important for them, because it's already part of their culture. The fences already limiting 
their activities. Before the projects, the local people can easily access the river for daily activities such as trading, washing etc (see Figure 3). The local people always avoid activities during daytime due to the high temperature and no sun shading. However, in the afternoon, children love to play with the water. They swam and canoeing along the river. The housewives used to open small shops in their terraces while the elders love to sit along the pathways, spending time with chatting, playing chess, etc. The neighbourhood full of friendly people and very open about their social life especially in the morning and in the afternoon.

After the water development project already been done, these activities are not happening again. Children rarely touch the water because their access is already blocked by the fences. Trading through the boat also difficult because the concrete pathways already too high to reach for the boat seller. Overall, the waterfront development project is more like a modernization and leaving the cultural aspects from local people. There is no connection between the river and the settlements.

(a)
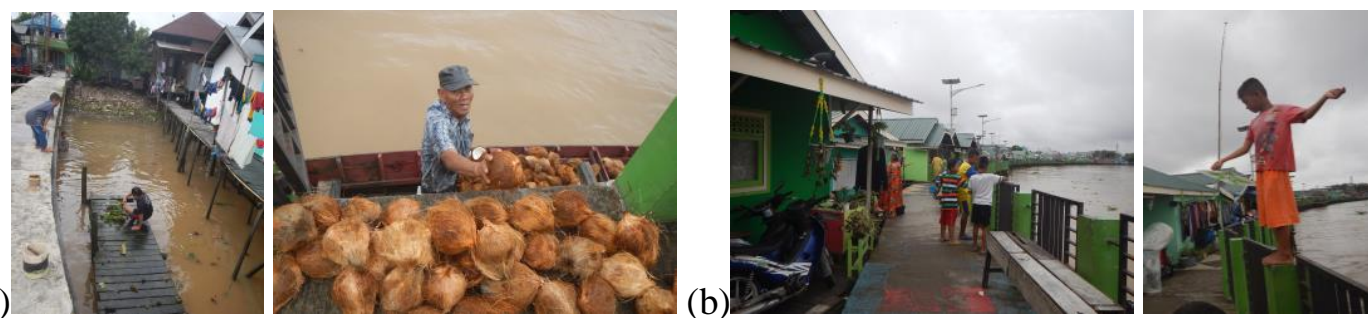

Figure 3. Activities in the Setllements along Martapura River before and after waterfront development (a) Before (b) July 2018After in 2016 and 2018

The local people in the settlements along Martapura river urgently need green open space. They mentioned two forms of open space, which are: (1) sport space and facilities, (2) children's playground with plenty of shades from trees or other canopies. These open spaces needed to connected with Martapura river, as river is an important thing in their culture and daily activities. The local people also concerns about how to improve the environmental quality of their neighbourhood, but they still have very little knowledge regarding the concept of green neighbourhood. They also aware that their settlements has very limited space and left no more open space for plantation, garden and park. This is a huge challenge for the neighbourhood. The neighbourhood need more than just potted plants as their greeneries.

\subsection{The Green Space Conceptual Design}

Almost all of the space in the neighbourhood is covered by buildings, therefore no space left for green space. The available quantity of green space in both the neighborhood are still far from the standard quantity of green space. Therefore, more efforts needed to be implemented in order to achieve the ideal green space in both settlement along Martapura River. Based on the existing condition and local people's aspirations, there are some special characteristic in settlements along Martapura river:

1. No land available for public green space, the only available space is the river and the concrete path.

2. There is no special guidelines specifically for green space in settlements along the river.

3. The local people like to plant local trees : pohon limau kuit (lime tree which fruits are small, taste tangy and sweet), Lombok tiung (small chillies which are very hot), and seledri (celery).

4. The green space design has to create a linkage with the tidal river (blue space).

5. The green space design has to create a space for social activities.

6. The green space design preferably low maintenance.

The main challenge is to design a green space which can fulfil the characteristic above. Normally, green space design for limited space often covers with vertical garden or roof garden. Nevertheless, several countries that have almost similar geographic condition with Banjarmasin have applied some designs for green space that used the edge of riparian areas. Some of the ideas combine the idea of floating garden and urban farming. 
As can be seen in Figure 4, the idea is creating floating garden on the surface of the river. Chicago already started a pilot project called "urban rivers" (Rivers, 2019) which aims to rehabilitate native vegetation to clean the river water. The city considers that their river already highly polluted and the gardens might bring local ecosystem like fish, birds and turtles to their habitat. This pilot project is already started since 2018 and succeed so far. It is also predicted to face some risks and challenges, especially about the cost and maintenance. The differences with Martapura river is that the river in Chicago is not a tidal river, while Martapura river has variation of high tide and low tide times. Tidal river can ruins the garden structure. This idea actually can be applicable in Banjarmasin with some variation on how to overcome the tidal time.

The other option for green space that connected to the river is called urban floating garden(Bajoria, 2015; Project, 2018; Rox, 2004). This idea already implemented in some cities in the world such as Rheine in Paris, Amsterdam and Sweden (Edelson, 2018; McClintock, 2010). The basic can be made from simple raft system or concrete. As for the settlements in Martapura river, the urgency is also about how to create a space to afford social activities. In other area, this problem is answered with a special floating communal space which can be combined with urban garden or urban farming that fills with local plantation. The cost of course would be higher because this concept of floating green communal space should be constructed on a concrete structure. Banjarmasin have some floating facilities such as: floating restaurant and floating health facilities that is more like a ship. The concept of floating communal space is not too large but still can provide enough space for social activities. The local people can use the space to plant some local vegetation (Pradhanang, Boving, \& Meisinger, 2019)and recreation. The other challenge is the tidal time and the stream or surface water movement caused by the water transportation.
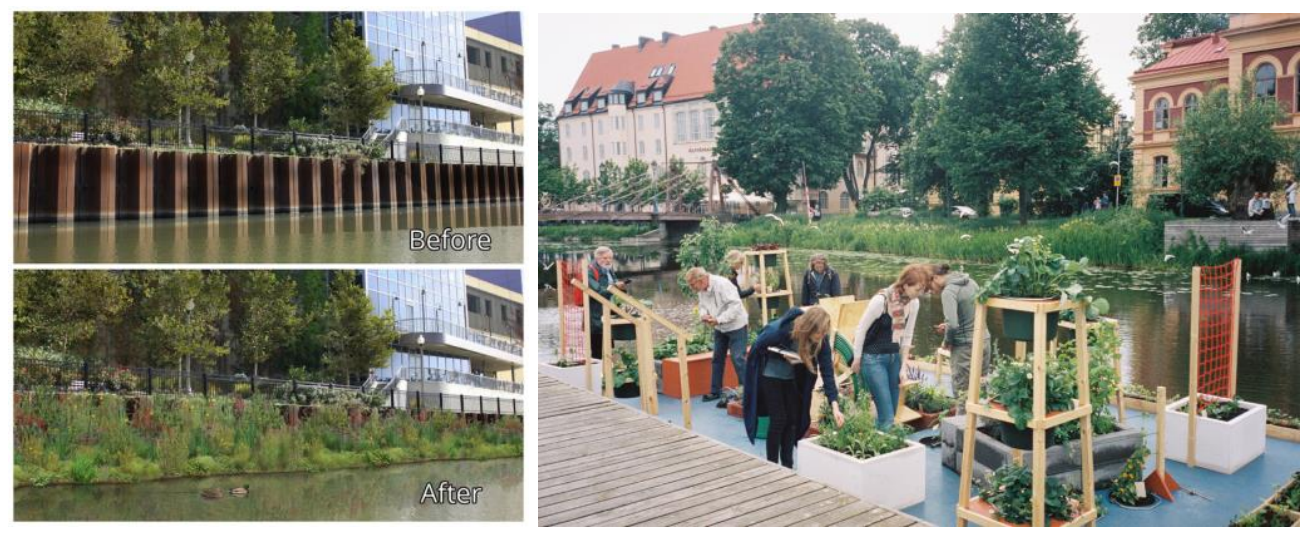

Figure 4. Floating garden in Chicago river (left) and floating communal space in Sweden (right) (Edelson, 2018; Rivers, 2019)

In order to create a greener environment, we need a more proper concept than just simply coloring the settlements into green. Therefore, we recommend three concept for a "Greener" green space concept that can be implemented in the neighbourhood based on the analysis above. The first one is to maximize the function of concrete pathways using vines plantation and potted plants. The idea is to create a thermal comfort and create shading for the neighborhood. We did not change any physical planning of the settlements, considering the green village project already gave quite a massive renovation to the material of the settlements. We chose to add a special feature to the front pathways where many local people tend to do their activities by the river from the afternoon until midnight. Vertical garden(Maks \& Hirmer, 2015)(Hien et al., 2010), vines plantation, or floating garden(Irfanullah, Adrika, Ghani, Khan, \& Rashid, 2008; Rox, 2004; The, 2005) might be a good solution.

The second concept is to add a floating communal space in some points along the neighbourhood, which can be functioned for doing social activities and creating a larger green space for the neighbourhood. Urban farming and urban garden (McClintock, 2010) with endemic vegetation is one of the possibility for the design in floating communal space. The third concept is based on the pilot project in Chicago (Rivers, 2019), where the river can be 
transformed with floating garden that has many function, especially cleaning the pollutant and creating better environment for the local ecosystem in the river.

As can be seen from Figure 5, the concept consists of potted plant along the walking path that easily can be watered everyday by the local people. As for the pergola concept, vines plantation might create a perfect shadow during daytime. The plantation can provide a better environment for the neighborhood, and create a greener neighborhood as well. This concept needs no extra space and covers the path perfectly from direct sunlight. The potted plants also giving another dimension to the façade of the settlements along the river. The selection of the plantation also can be so variative and opens new opportunity for urban farming, aside from decorative plants. Local people can plant chilies, tomatoes, tangerine, etc by using plastic pipe that filled with soil and water hyacinth as the basic media. It is better if the plantation can come from the local vegetation and also used to clear the pollutants from the river (Pradhanang et al., 2019).

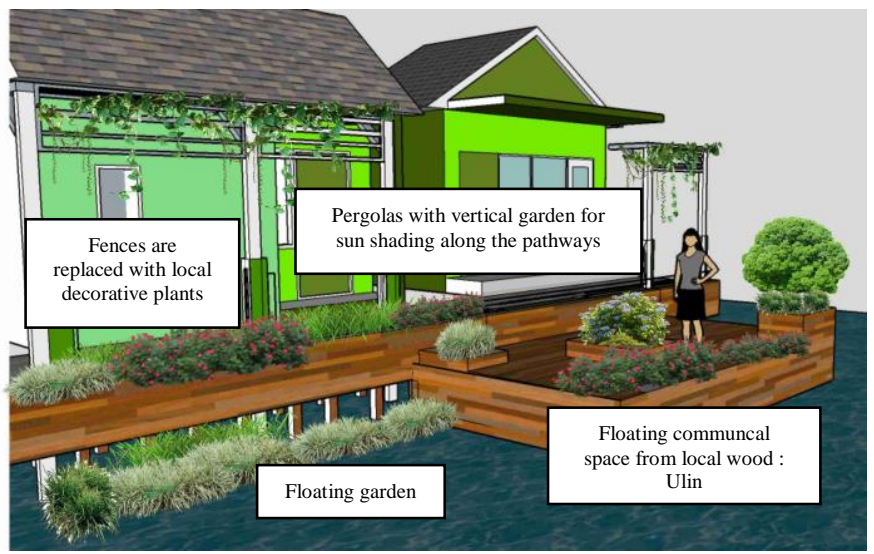

Figure 5. The Conceptual Design illustration for Green Space along Martapura River (Analysis, 2019)

There are so many pathways design along the river in many cities in the world (which sometimes also called as promenade), with no fences. The purpose of the design is to create a better relation between the land and the river, or between the green space and the blue space. In the research area, it will be better if the fences can be removed and replaced with a natural hedge from bushes or small decorative plants, so there is still a boundaries between the settlements and the river. The open space between the settlements and Martapura river is the true local identity of the neighbourhood along Martapura river. The materials need to be more localize, instead of concrete. Local wood such as Ulin wood might be a good choice, or other materials, which can give the same visual as wood.

\section{Conclusions}

The existing condition of the case study are different with the term of "riverside settlements" or "riverfront settlements", because the settlements along Martapura river are built directly above the river without no ground. Both settlement along Martapura River has shown that the main problem to provide green space along the Martapura River is the limited land available to plant vegetation, green belt, big trees, etc. The previous environmental projects called "Green Village" successfully installed some greeneries to the neighborhood, but is it enough to create a greener neighborhood? Public green space almost impossible to be placed in the neighborhood. Consequently, special green space design and plan needed to be developed in settlement along Martapura River of Banjarmasin.

The conceptual design that we produce after the analysis shows that there is a chance to create a greener neighborhood in the settlements along Martapura river through 3 concept. The first one is to install pergolas where vertical garden can grow and provide sun shading. The second one is to make a floating communal space which can turn into urban farming, playgrounds, etc. The third one is the floating garden which already succeeded implemented in many other cities in the world. 
We consult and give a presentation regarding these basic ideas to the local people and most of them give many positive feedbacks. They said the main problem of their neighborhood is there are no available space to plant big trees for sun shading. The pergola seems to be a good idea to protect their neighborhood from direct sunlight and heat because it will not need such large space. The local people also think that the idea of vertical garden can be implemented in their neighborhood, but not in full form, considering their limited spaces. The pathways only around 1 metre wide, so the concept of the pergola will not use any space from the pathways. This concept will need to be implemented to assess it. A pilot project would be a good start to implement this concept and later can be assessed for further research.

After consultation with the local people of Seberang Mesjid and Sungai Bilu's district, it will be a bit hard to put floating gardens along the river. The river is constantly use as water transportation, and this has made the water keep moving in many ways. Floating garden needs a calm water environment such as ponds or lakes. Therefore, even floating garden was considered as a good idea, the existing condition of the river may not be supportive for the floating garden. However, there is an idea on how to anchor the basic foundation of the floating garden to the settlements wooden structure or put a ballast below the floating garden and communal space. Therefore, further research especially with a pilot project will be best to evaluate the best concept for green space design along Martapura river.

\section{References}

Bajoria, S. (2015). Floating Gardens. Retrieved September 20, 2018, from https://www.greenmylife.in/floating-gardens/

Bank, A. D. (2012). Green Cities - A Sustainable Urban Future in Southeast Asia.

Caesarina, H. M., \& Aina, N. (2018). Green Space Impacts in Stream Corridor Settlement as an Effort to Form a "Greener" Neighborhood. ESE International Journal (Environmental Science and Engineering), 1(1), 1-5.

Caesarina, H. M., Humaida, N., Amali, M. F., \& Wahyudi, M. W. (2019). The Need of Green Open Spaces as the Effect of Urban Waterfront Development in Sungai Bilu, a Stream Corridor Neighbourhood in Banjarmasin. In MATEC Web of Conferences (Vol. 280, p. 03015). https://doi.org/10.1051/matecconf/201928003015

Cities, S. (2010). Iii.3 planning for resilient and sustainable cities 143.

Darieva, T. (2015). Modernising the waterfront: urban green, built environment and social life of the Baku promenade. Europa Regional, 1-2, 65-79.

Direktorat Jendral Penataan Ruang. Department Pekerjaan Umum. Pedoman Penyediaan Dan Pemanfaatan Ruang Terbuka Hijau Di Kawasan Perkotaan, Pedoman Penyediaan Dan Pemanfaatan Ruang Terbuka Hijau Di Kawasan Perkotaan § (2008).

Dwiyanto, A. (2009). Kuantitas Dan Kualitas Ruang Terbuka Hijau Di Permukiman Perkotaan. Teknik, 30(2), 88-93. https://doi.org/10.1017/CBO9781107415324.004

Edelson, Z. (2018). Uppsala Builds Floating Pocket Park to Promote Urban Farming. Retrieved September 20, 2018, from https://www.metropolismag.com/cities/uppsala-builds-floating-pocketpark-promote-urban-farming/

El Ghorab, H. K., \& Shalaby, H. A. (2016). Eco and Green cities as new approaches for planning and developing cities in Egy pt. Alexandria Engineering Journal, 55(1), 495-503. https://doi.org/10.1016/j.aej.2015.12.018

Goell, E., Nisreen, E.-L., Hussen, W., El-Khishin, S., \& Soliman, S. (2009). Sustainable Cities in Egypt Learning from Experience: Potentials and Preconditions for New Cities in Desert Areas Sustainable Cities in Egypt 1, (September), 111. Retrieved from http://csfs.bue.edu.eg/files/Library/Papers/SustainableCitiesinEgypt.pdf

Goenmiandari, B. (2010). Konsep Penataan Permukiman Bantaran Sungai di Kota Banjarmasin berdasarkan Budaya Setempat Concept of Local Culture Based Riverbank Settlement Arrangement in Banjarmasin, 1-14.

Hagerman, C. (2007). Shaping neighborhoods and nature: Urban political ecologies of urban waterfront transformations in Portland, Oregon. Cities, 24(4), 285-297. https://doi.org/10.1016/j.cities.2006.12.003

Hartig, T., Mitchell, R., de Vries, S., \& Frumkin, H. (2014). Nature and Health. Annual Review of Public Health, 35(1), 207-228. https://doi.org/10.1146/annurev-publhealth-032013-182443

Hien, N., Yong, A., Tan, K., Chen, Y., Sekar, K., Yok, P., ... Chung, N. (2010). Thermal evaluation of vertical greenery systems for building walls. Building and Environment, 45(3), 663-672. https://doi.org/10.1016/j.buildenv.2009.08.005 
Irfanullah, H. M., Adrika, A., Ghani, A., Khan, Z. A., \& Rashid, M. A. (2008). Introduction of floating gardening in the north-eastern wetlands of Bangladesh for nutritional security and sustainable livelihood. Renewable Agriculture and Food Systems, 23(2), 89-96. https://doi.org/10.1017/S1742170507002074

Johar, F., \& Razak, M. R. (2015). The Right Attitude to Sustain the Green Neighbourhoods. Procedia Social and Behavioral Sciences, 202(December 2014), 135-143. https://doi.org/10.1016/j.sbspro.2015.08.216

Lin, E., Shaad, K., \& Girot, C. (2016). Developing river rehabilitation scenarios by integrating landscape and hydrodynamic modeling for the Ciliwung River in Jakarta, Indonesia. Sustainable Cities and Society, 20, 180-198. https://doi.org/10.1016/j.scs.2015.09.011

Maks, M., \& Hirmer, S. (2015). The potential for vertical gardens as evaporative coolers : An adaptation of the ' Penman Monteith Equation .' Building and Environment, 92, 135-141. https://doi.org/10.1016/j.buildenv.2015.03.033

McClintock, N. (2010). Why farm the city? Theorizing urban agriculture through a lens of metabolic rift. Cambridge Journal of Regions, Economy and Society, 3(2), 191-207. https://doi.org/10.1093/cjres/rsq005

Nurisyah, S. and L. A. (2011). Perencanaan Lanskap Riparian Sungai Martapura Untuk Meningkatkan Kualitas Lingkungan Alami Kota Banjarmasin. Jurnal Lanskap Indonesia, 3(1), 21-26.

Pekerjaan Umum dan Perumahan Rakyat, K., Jenderal Cipta Karya, D., \& Bina Penataan Bangunan, D. (2017). Panduan penyelenggaraan Program Pengembangan Kota Hijau (VI). Jakarta: Kemeterian Pekerjaaan Umum dan Perumahan Rakyat, Direktorat Jenderal CIpta Karya, Direktorat Bina Penataan Bangunan.

Pradhanang, S. M., Boving, T., \& Meisinger, E. (2019). Floating Wetlands System : A viable alternative for water pollutants remediation. In MATEC Web of Conferences (Vol. 5001). EDP SCiences.

Project, F. G. (2018). a Floating Gardens Project. Retrieved September 20, 2018, from http://savelakeatitlan.com/floating-gardens-project/

Riddell, R. (2004). Sustainable Urban Planning. https://doi.org/10.1002/9780470773703

Rivers, U. (2019). Floating Gardens in the Chicago River. Retrieved February 5, 2019, from https://www.kickstarter.com/projects/wildmile/floating-gardens-in-the-chicago-river

Rox, S. (2004). Modular Floating Decorative Garden and Related Water Quality Process. United States.

Sandhu, S. C., \& Singru, R. N. (2014). Enabling GrEEEn Cities: An Operational Framework for Integrated Urban Development in Southeast Asia. ADB Southeast Asia Working Paper Series, (9). Retrieved from www.adb.org

The, I. (2005). The Floating Gardens In Mexico Xochimilco, World, 1(3), 47-57.

Tzoulas, K., Korpela, K., Venn, S., Yli-Pelkonen, V., Kaźmierczak, A., Niemela, J., \& James, P. (2007). Promoting ecosystem and human health in urban areas using Green Infrastructure: A literature review. Landscape and Urban Planning, 81(3), 167-178. https://doi.org/10.1016/j.landurbplan.2007.02.001

Wolch, J. R., Byrne, J., \& Newell, J. P. (2014). Urban green space, public health, and environmental justice: The challenge of making cities "just green enough." Landscape and Urban Planning, 125, 234-244. https://doi.org/10.1016/j.landurbplan.2014.01.017

World Health Organization. (2017). Urban green spaces: a brief for action. Retrieved from http://www.euro.who.int/__data/assets/pdf_file/0010/342289/Urban-GreenSpaces_EN_WHO_web.pdf

Wright, N. G., Thorne, Co. R., \& Lawson, E. (2014). Delivering and evaluating the multiple flood risk benefits in Blue-Green cities: An interdisciplinary approach. In 11th International Conference on Hydroinformatics HIC 2014, New York City, USA (Vol. 184, pp. 113-124). New York: WIT Transactions on Ecology and the Environment. https://doi.org/10.2495/FRIAR140101

Yassin, A. B., Eves, C., \& Mcdonagh, J. (2010). An evolution of waterfront development in Malaysia. 16th Pacific Rim Real Estate Society Conference, (January), 1-14. Retrieved from http://researcharchive.lincoln.ac.nz/handle/10182/3215 